\title{
МОРФОЛОГІЧНІ ОСОБЛИВОСТІ М'ЯЗОВОГО ТА СТРОМАЛЬНОГО КОМПОНЕНТІВ МІОКАРДА ЗАЛЕЖНО ВІД ВІКУ ЗА УМОВ ЕКСПЕРИМЕНТАЛЬНОЇ ГІПЕРХОЛЕСТЕРОЛЕМІї
}

\author{
๑О. І. Гладій, Я. Я. Боднар, Л. П. Боднар
}

Тернопільський національний медичний університет імені І. Я. Горбачевського МОз України

РЕЗЮМЕ. У статті проаналізовано зміни міокарда, виявлені гістологічно та гістохімічно, за умов експериментальної гіперхолестеролемії у тварин пубертатного та зрілого віку. Перебудова міокарда за цих умов пов'язана 3 гіпертрофією кардіоміоцитів в обох вікових групах, у тварин зрілого віку - також із їх атрофією та некрозом, а також дезорганізацією стромального компонента, що проявляється накопиченням різного ступеня нейтральних глікозаміногліканів та кислих мукополісахаридів.

Мета - з'ясувати особливості морфологічних змін кардіоміоцитів та екстрацелюлярного матриксу міокарда щурів пубертатного та зрілого віку за умов експериментальної гіперхолестеролемії.

Матеріал і методи. Дослідження проведені на 24 білих нелінійних щурах-самцях. Для моделювання експериментальних метаболічних порушень залучали здорових тварин пубертатного та зрілого віку. Гіперхолестеролемію моделювали протягом 30 діб шляхом згодовування холестеролу, розчиненого в соняшниковій олії, на фоні пригнічення функції щитоподібної залози мерказолілом. Гістологічні зрізи фарбували гематоксиліном і еозином, пікрофуксином за ван Гізон, залізним гематоксиліном за Гейденгайном, альціановим синім за Стідменом, досліджено PAS-реакцією.

Результати. В обох досліджуваних вікових групах підвищення загального холестеролу в крові супроводжувалось морфологічними змінами в міокарді. Гістохімічне дослідження підтверджує суттєві прояви дезорганізації стромального компонента міокарда за умов експериментальної гіперхолестеролемії, які відображаються накопиченням нейтральних глікозаміногліканів та кислих мукополісахаридів. Вираженіші прояви дезорганізації сполучної тканини інтерстицію міокарда спостерігали у тварин зрілої вікової групи. Зміни скоротливого апарату міокарда проявлялися гіпертрофією в обох вікових групах, в зрілій віковій групі, крім цього, виявляли атрофічні та некротичні зміни.

Висновки. За умов експериментальної гіперхолестеролемії у щурів пубертатного віку ремоделювання кардіоміоцитів має пристосувальне спрямування і проявляється їх гіпертрофією, а зрілого віку, навпаки, - альтеративне, як прояв зриву компенсаторних можливостей. В екстрацелюлярному матриксі молодих тварин переважають явища інтерстиціального та периваскулярного набряку, а у щурів зрілого віку - дифузного і периваскулярного склерозу.

КлючовІ СловА: міокард; гіперхолестеролемія; експеримент; морфологія.

Вступ. Серцево-судинна патологія займає провідне місце у структурі захворюваності населення і $\epsilon$ головною причиною смертності [1]. 3'ясовано чимало етіопатогенетичних факторів їх розвитку та прогресування. Однак основним результатом наукових досліджень залишається взаємозв'язок між розвитком серцево-судинних захворювань та дисліпідеміями $[2,3]$. Попри це актуальною залишається проблема з'ясування та уточнення структурних особливостей ремоделювання міокарда за умов дисліпідемій, що відображається у порушенні його нормальної функції [4]. Морфофункціональний стан кардіоміоцитів тісно залежить від структурного стану екстрацелюлярного матриксу, який виконує роль каркаса та середовища взаємодії кардіоміоцитів [5] і має свої особливості перебудови, залежно від причини. Відомо, що навантаження на серцевий м'яз супроводжуються збільшенням сили скорочення, потребують відповідного ущільнення колагенової сітки, яке призводить до виникнення реактивного або додаткового фіброзу. При запаленні ха- рактер фіброзу найімовірніше комбінований, оскільки пошкоджуються як м'язові волокна, так і сама колагенова сітка [6]. Гіпоксичне пошкодження міокарда супроводжується некрозом міоцитів, на місці яких розвивається репаративний фіброз, при цьому нові колагенові волокна заповнюють місце кардіоміоцитів [7]. На відміну від вказаного, наше дослідження полягало у з'ясуванні характеру змін міокарда при експериментальній гіперхолестеролемії у віковому аспекті.

Мета - з'ясувати особливості морфологічних змін кардіоміоцитів та екстрацелюлярного матриксу міокарда щурів пубертатного та зрілого віку за умов експериментальної гіперхолестеролемії.

Матеріал і методи дослідження. Дослідження проведені на 24 білих нелінійних щурах-самцях. Роботу із піддослідними тваринами виконували згідно з правилами Європейської конвенції про гуманне ставлення до лабораторних тварин (Страсбург, 1985), Загальними етичними принципами експериментів на тваринах, ухваленими Першим національним конгресом з біоетики (Київ, 2001). 
Огляди літератури, оригінальні дослідження, погляд на проблему, випадок з практики, короткі повідомлення

Для моделювання експериментальних метаболічних порушень залучали здорових тварин двох вікових груп: починаючи з пубертатного віку (3 міс., 3 середньою масою 110-130 г) та починаючи із зрілого віку (12 міс., з середньою масою 230-250 г). Відбір щурів здійснювали згідно з рекомендаціями Гуськової Т. А. [8], враховуючи відповідність віку тварин до віку людей. Виведення лабораторних тварин з експерименту здійснювали шляхом декапітації після знеболювання внутрішньоочеревинним введенням тіопенталу натрію в дозі 50 мг/кг. Контрольні групи складали інтактні щури відповідного віку.

Гіперхолестеролемію моделювали шляхом згодовування тваринам холестеролу, розчиненого в соняшниковій олії, в дозі 0,5 г/кг, та мерказолілу в дозі 10 мг/кг з метою пригнічення функції щитоподібної залози [9]. Зміни, що розвивались, оцінювали через 30 діб. Рівень холестеролемії визначали ферментативним методом на напівавтоматичному біохімічному аналізаторі «Humalyzer 2000» (Німеччина) з використанням стандартного набору реактивів «Human» (Німеччина). Через 30 діб експерименту рівень загального холестеролу в крові тварин обох досліджуваних груп зріс у понад 2 рази проти контрольних. Тканину міокарда фіксували в 10 \% розчині нейтрального формаліну, зневоднювали у спиртах зростаючої концентрації та ущільнювали в парафіні. Гістологічні зрізи фарбували гематоксиліном і еозином, пікрофуксином за ван Гізон, залізним гематоксиліном за Гейденгайном. Гістохімічне дослідження зрізів міокарда полягало у виявленні нейтральних глікозаміногліканів за допомогою PAS-реакції, а кислих несульфатованих - фарбуванням альціановим синім за Стідменом [10]. Аналіз гістологічних змін міокарда здійснювали за допомогою мікроскопів SEOSCAN, Люмам P-8 та МБИ-15 при різних збільшеннях. Для фотодокументування зображення з мікроскопів виводили на монітор комп'ютера за допомогою відеокамери VISION Color CCD Camera і програми InterVideoWinDVR. Аналіз цифрових результатів виконаний за допомогою методів варіаційної статистики з використанням програми «Microsoft Excel 2016» та «Statistica 10.0». У зв'язку із відсутністю нормального закону розподілу для статистичної оцінки значимості різниці між середніми величинами у вибірках використовували непараметричний метод U-тест Манна-Уїтні. Достеменними вважали відмінності при р $\leq 0,05$ (95,5\%).

Результати й обговорення. У тварин, яких утримували протягом 30 діб на гіперхолестероловій дієті, зареєстровано порушення всіх структурних компонентів міокарда, насамперед кардіоміоцитів і судин. Ремоделювання стінки арте- рій у щурів зрілого віку проявились набубнявінням ендотеліоцитів та гіперплазією гладких міоцитів, а також інфільтрацією субінтимального шару ксантомними клітинами. Однак у тварин обох вікових груп у просвіті артерій відмічено крайове розміщення плазми із просяканням судинної стінки, що зумовлювало периваскулярний та інтерстиціальний набряк (рис. 1). При забарвленні за ван Гізон периваскулярно спостерігали ніжну сіточку колагенових волокон. Окрім цього, відмічали діапедезні крововиливи.

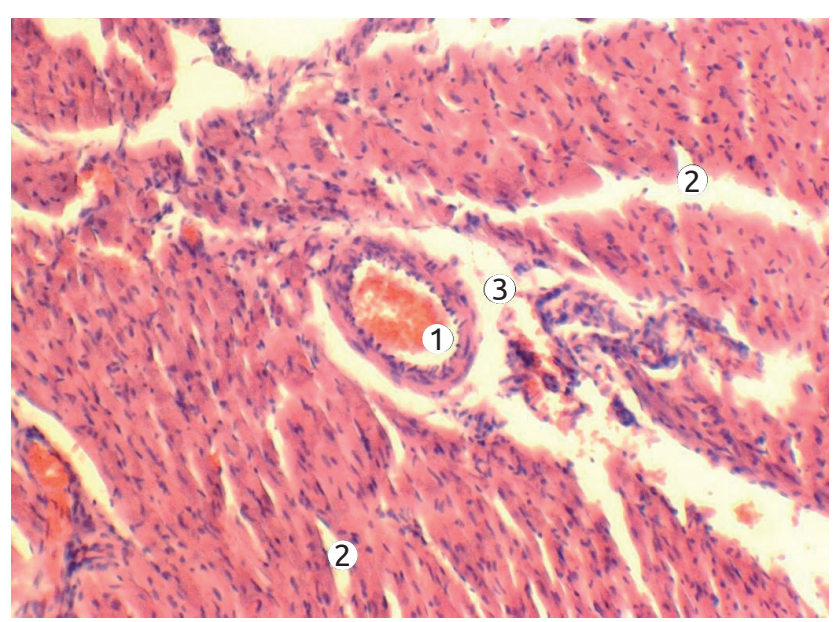

Рис. 1. Міокард щура зрілого віку. Моделювання експериментальної гіперхолестеролемії: 1 - повнокров'я судин; 2 - стромальний набряк; 3 - периваскулярний набряк. Забарвлення гематоксиліном та еозином. $\times 100$.

У молодих тварин сформувались помірні зміни м'язових волокон, помітна значна кількість гіпертрофованих клітин. При фарбуванні за Гейденгайном ділянки з ослабленням посмугованості більш інтенсивно профарбовувалися залізним гематоксиліном, однак вони розташовувались у товщі міокарда поодиноко серед незмінених кардіоміоцитів.

У молодих тварин було відмічено поодинокі помірно потовщені судини, переважно спазмовані або з явищами гіперемії. Внаслідок таких змін у цій експериментальній групі спостерігали гіпертрофовані кардіоміоцити зі втратою поперечної посмугованості, а в стромі - прояви набряку.

Зміни гістоструктури міокарда тварин зрілого віку відображають прогресування дистрофічноциркуляторних змін. Виявляли спазмовані судини, в яких інтима була гофрованою, а середня оболонка потовщеною. В субепікардіальних ділянках відмічали паретично змінені судини, які виглядали повнокровними, ендотеліоцити в них були ущільнені, внаслідок чого інтима ставала згладженою. Ці зміни поєднувались із стромальними, які здебільшого характеризувались розвит- 
Огляди літератури, оригінальні дослідження, погляд на проблему, випадок з практики, короткі повідомлення ком склерозування. Однак у ділянках між стромальними проміжками зустрічались кардіоміоцити не лише гіпертрофовані, а й з ознаками атрофії.

Зріс відсоток гіперацидофільних кардіоміоцитів, ядра спостерігали не лише великі гіперхромні, а й зморщені інтенсивно забарвлені. Клітини були переважно гіпертрофовані, ядра втрачали овальну форму, розташовувались центрально, поодиноко і під сарколемою. Цитоплазма нерівномірно забарвлювалась, з'являлась зернистість. Спостерігали групове розташування Гейденгайнпозитивних клітин, що захоплювали декілька сегментів кардіоміоцитів і локалізувались переважно периваскулярно (рис. 2).

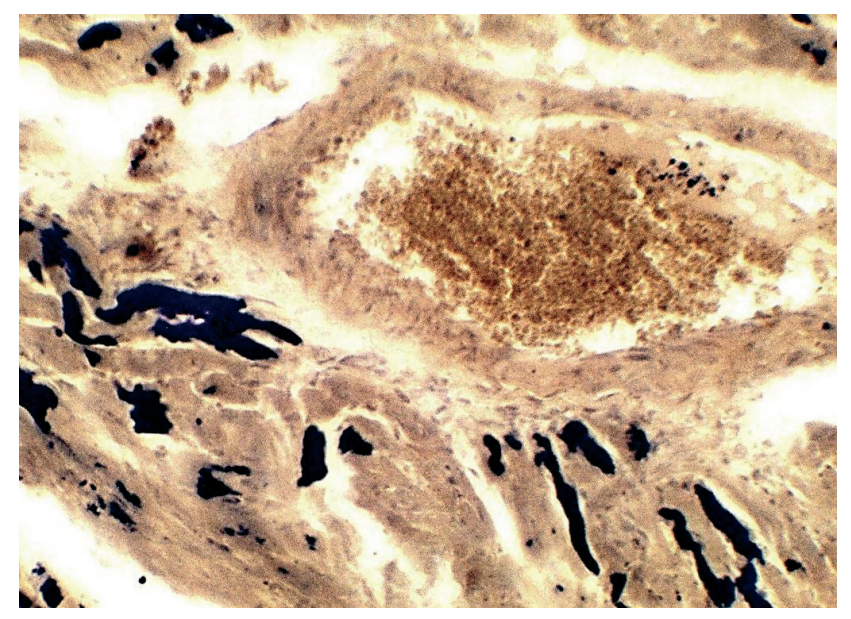

Рис. 2. Периваскулярні осередки некротизованих кардіоміоцитів. Гістологічний зріз міокарда тварини зрілого віку при експериментальній гіперхолестеролемії. Забарвлення за Гейденгайном. ×400.

У зрілих тварин із змодельованою гіперхолестеролемією, поряд із гістологічними проявами ушкоджень м'язових волокон, виявили суттєві прояви дезорганізації стромального компонента, які виражались у розширенні стромальних прошарків із порівняно більшою кількістю фіброцитів та колагенових волокон. Структурні зміни позаклітинного матриксу проявлялися розвитком периваскулярного та інтерстиціального склерозу. У периваскулярних ділянках при забарвленні альціановим синім за Стідменом виявили ділянки метахромазії, що свідчить про накопичення кислих мукополісахаридів.

В основній речовині ендомізію міокарда зрілих тварин контрольної групи реакція на кислі полісахариди дуже слабка, однак, на відміну від тварин пубертатного віку, вона більш виражена, що вказує на вікову різницю вмісту глікозаміногліканів у стромі міокарда.

У тварин пубертатного віку ознаки метахромазії при експериментальній гіперхолестеролемії були незначно вираженими. У зрілих тварин

були наявні прояви різного ступеня експресії кислих мукополісахаридів, які мали дифузний характер накопичення в інтерстиції (рис. 3).

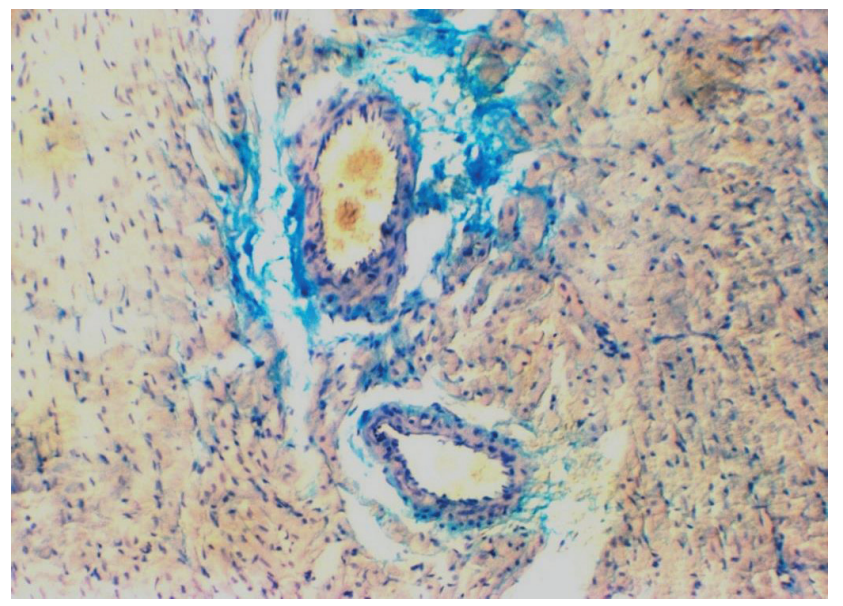

Рис. 3. Прояви метахромазії в стінці судин та периваскулярному просторі міокарда щура зрілого віку. Експериментальна гіперхолестеролемія. Забарвлення альціановим синім за Стідменом. ×120.

При холестероловому навантаженні накопичення нейтральних мукополісахаридів у першу чергу виявляли в судинній стінці та периваскулярному просторі. Просякання PAS-позитивними субстанціями стінки судин відмічали у тварин обох вікових груп. У щурів пубертатного віку характер їх накопичення був неоднорідним. Більш поширеними виявились ознаки цієї дистрофії в тварин зрілого віку (рис. 4).

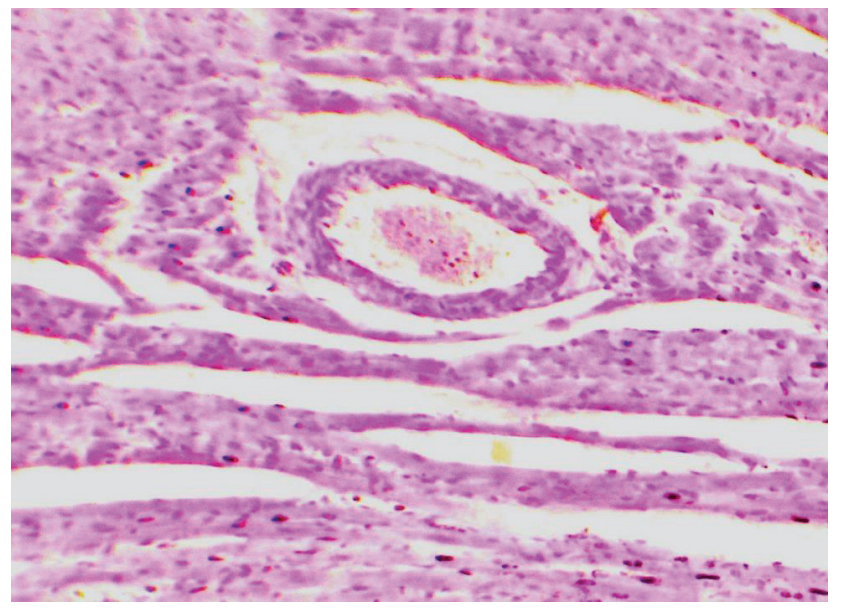

Рис. 4. Гістологічний зріз міокарда щура зрілого віку. Інтрамуральна та периваскулярна локалізація нейтральних глікозаміногліканів у кардіоміоцитах та стромі міокарда. Експериментальна гіперхолестеролемія. PAS-реакція. $\times 120$.

Накопичення кислих мукополісахаридів в основній речовині передує появі волокнистих структур, що дозволяє розцінювати дане явище як пе- 
Огляди літератури, оригінальні дослідження, погляд на проблему, випадок з практики, короткі повідомлення редсклерозивний стан, а зростання експресії нейтральних мукополісахаридів підтверджує набряк периваскулярних просторів та строми міокарда.

Висновки. За умов експериментальної гіперхолестеролемії у щурів пубертатного віку ремоделювання кардіоміоцитів має пристосувальне спрямування і проявляється їх гіпертрофією, а зрілого віку, навпаки, - альтеративне, як прояв зриву компенсаторних можливостей.

\section{ЛІТЕРАТУРА}

1. Серцево-судинні захворювання - головна причина смерті українців. Висновки з дослідження глобального тягаря хвороб у 2019 р. [Електронний ресурс] / Центр громадського здоров'я МОЗ України. - Режим доступу: https://phc.org.ua/news/sercevo-sudinni-zakhvoryuvannyagolovna-prichina-smerti-ukrainciv-visnovki-z-doslidzhennya.

2. Giddini S. S. Cholesterol and atherosclerotic cardiovascular disease: a lifelong problem / S. S. Giddini, N. B. Allen // J. Am. Heart Assoc. - 2019. - Vol. 8 (11). - e012924.

3. Гайдук Т. А. Взаємозв'язок гіпертрофії міокарда лівого шлуночка та дисліпідемії у дітей та підлітків з артеріальною гіпертензією / Т. А. Гайдук, Л. Р. Шостакович-Корецька, О. І. Гайдук // Здобутки клініч. і експерим. медицини. - 2020. - № 3. - С. 61-65.

4. Yao Y. S. Mechanism underlying direct actions of hyperlipidemia on myocardium: an updated review / Y. S. Yao, T. D. Li, T. H. Zeng // Lipids Health Dis. - 2020. - № 19 (23).

5. Бильдюг И. Б. Зависимость организации сократительного аппарата кардиомиоцитов от внеклеточного матрикса / И. Б. Бильдюг, Г.П.Пинаев // Цитология. 2013. - T. 55, № 10 - С. 713-724.

\section{REFERENCES}

1. Tsentr hromadskoho zdorovia MOZ Ukrainy. (2019). Sertsevo-sudynni zakhvoriuvannia - holovna prychyna smerti ukraintsiv. Vysnovky z doslidzhennia hlobalnoho tiaharia khvorob u 2019 r. [Center for Public Health of the Ministry of Health of Ukraine. Cardiovascular diseases - the main cause of death of Ukrainians. Conclusions from the study of the global burden of disease in 2019]. Retrieved from: https://phc.org.ua/news/sercevo-sudinni-zakhvoryuvannyagolovna-prichina-smerti-ukrainciv-visnovki-z-doslidzhennya.

2. Giddini, S.S., \& Allen, N.B. (2019). Cholesterol and atherosclerotic cardiovascular disease: a lifelong problem. J. Am. Heart Assoc., 8(11), e012924. DOI: 10.1161/ JAHA.119.012924

3. Haiduk, T.A., Shostakovych-Koretska, L.R., \& Haiduk, O.I. (2020). Vzaiemozviazok hipertrofii miokarda livoho shlunochka ta dyslipidemii u ditei ta pidlitkiv $z$ arterialnoiu hipertenziieiu [Relationship between left ventricular myocardial hypertrophy and dyslipidemia in children and adolescents with arterial hypertension]. Zdobutky klinich. i eksperym. medytsyny - Achievements of Clinical and Experimental Medicine, 3, 61-65. DOI: 10.11603/18112471.2020.v.i3.11584 [in Ukrainian].

4. Yao, Y.S., Li, T.D. \& Zeng, Z.H. (2020). Mechanisms underlying direct actions of hyperlipidemia on myocardium: an updated review. Lipids. Health Dis., 19, 23 DOI: https:// doi.org/10.1186/s12944-019-1171-8

5. Bildyug, I.B., \& Pinayev, G.P. (2013). Zavisimost organizatsii sokratitelnogo apparata kardiomiotsitov ot vnekletochnogo matriksa [Extracellular matrix dependence of organization of the cardiomyocyte contractile apparatus]. Tsitologiya - Cell Tiss. Biol., 55, 10, 713-724. DOI: 10.1134/ S0041377119040072 [in Russian].

6. Rienks, E.M., Papageorgiou, A.-P., Frangogiannis, N.G., \& Heymans, S. (2014). The myocardial extracellular matrix: an ever-changing and diverse. Circ. Res., 114, 872888. DOI: 10.1161/CIRCRESAHA.114.302533

7. Blagodarov, V.N., Danilishina, M.V., Lagoda, N.N., \& Rudnitskaya, O.G. (2011). Morfogeneticheskiye aspekty izmeneniy miokarda v usloviyakh ostroi i khronicheskoi ishemii [Morphogenetic aspects of myocardial changes in acute and chronic ischemia]. Zaporozh. med. zhurn. - Zaporozhye Medical J., 13, 6, 10-13 [in Russian].

8. Guskova, T.A. (2001). Kontseptsiya razvitiya lekarstvennoi toksikologii [The concept of development of 
Огляди літератури, оригінальні дослідження, погляд на проблему, випадок з практики, короткі повідомлення drug toxicology]. Khim. farm. zhurn. - Chem. Farm. J., 35, 10, 3-8 [in Russian].

9. Piskun, R.P., Hrynchak, N.M. (2011). Osoblyvosti mikromorfometrychnykh zmin struktur sertsia pry eksperymentalnomu aterosklerozi ta yoho hennii korektsii [Peculiarity of micromorphometric changes in the structures of the heart in experimental atherosclerosis and its genetic correction]. Visnyk problem biolohiyi i medytsyny - Bull. Probl. Biol. Med., 3, 2, 147-150 [in Ukrainian].

10. Bahrii, M.M., \& Dibrova, V.A. (Eds.). (2016). Metodyky morfolohichnykh doslidzhen: monohrafiia [Methods of morphological research: a monograph]. Vinnytsia: Nova knyha [in Ukrainian].

\title{
МОРФОЛОГИЧЕСКИЕ ОСОБЕННОСТИ МЫШЕЧНОГО И СТРОМАЛЬНОГО КОМПОНЕНТОВ МИОКАРДА В ЗАВИСИМОСТИ ОТ ВОЗРАСТА ПРИ ЭКСПЕРИМЕНТАЛЬНОЙ ГИПЕРХОЛЕСТЕРОЛЕМИИ
}

\author{
○Е. И. Гладий, Я. Я. Боднар, Л. П. Боднар \\ Тернопольский национальный медицинский университет имени И. Я. Горбачевского МОз Украины
}

\begin{abstract}
РЕЗЮМЕ. В статье проанализированы гистологические и гистохимические изменения миокарда в условиях экспериментальной гиперхолестеролемии у животных пубертатного и зрелого возраста. Перестройка миокарда в указанных условиях связана с гипертрофией кардиомиоцитов у крыс обеих возрастных групп, что сочетается с их атрофией и некрозом у животных зрелого возраста, а также с дезорганизацией стромального компонента, что проявляется накоплением различной степени нейтральных гликозаминогликанов и кислых мукополисахаридов.

Цель - определить особенности морфологических изменений кардиомиоцитов и экстрацеллюлярного матрикса миокарда крыс пубертатного и зрелого возраста в условиях экспериментальной гиперхолестеролемии.

Материал и методы. Исследования проведены на 24 белых нелинейных крысах-самцах. Моделирование экспериментальных метаболических нарушений было проведено у здоровых животных пубертатного и зрелого возраста. Гиперхолестеролемию моделировали в течение 30 суток путем скармливания холестерина, растворенного в подсолнечном масле, на фоне угнетения функции щитовидной железы мерказолилом. Гистологические срезы окрашивали гематоксилином и эозином, пикрофуксином по ван Гизон, железным гематоксилином по Гейденгайну, альциановым синим по Стидмену, обработано PAS-реакцией.

Результаты. У животных обеих возрастных исследуемых групп повышение общего холестерина в крови сопровождалось морфологическими изменениями в миокарде. Гистохимическое исследование подтверждает существенные проявления дезорганизации стромального компонента миокарда в условиях экспериментальной гиперхолестеролемии в виде накопления нейтральных гликозаминогликанов и кислых мукополисахаридов. Более выраженые проявления дезорганизации соединительной ткани интерстиция миокарда наблюдали у животных зрелой возрастной группы. Изменения сократительного аппарата миокарда проявлялись гипертрофией кардиомиоцитов в обеих возрастных группах. У животных зрелой возрастной группы наблюдались также атрофические и некротические изменения.

Выводы. В условиях экспериментальной гиперхолестеролемии у крыс пубертатного возраста ремоделирование кардиомиоцитов имеет приспособительное направление и проявляется их гипертрофией, а зрелого возраста, наоборот, альтеративное, как проявление срыва компенсаторных возможностей. В экстрацеллюлярном матриксе молодых животных преобладают явления интерстициального и периваскулярного отека, а у крыс зрелого возраста - диффузного и периваскулярного склероза.
\end{abstract}

КЛючЕВЫЕ СЛОВА: миокард; гиперхолестеролемия; эксперимент; морфология.

\section{MORPHOLOGICAL PECULIARITIES OF MUSCULAR AND STROMAL COMPONENTS OF MYOCARDIUM DEPENDING ON AGE UNDER EXPERIMENTAL HYPERCHOLESTEROLEMIA}

\author{
๑O. I. Hladii, Ya. Ya. Bodnar, L. P. Bodnar \\ I. Horbachevsky Ternopil National Medical University
}

SUMMARY. The article analyzes histological and histochemical morphological changes of myocardium in the conditions of experimental hypercholesterolemia in animals of pubertal and mature age. Myocardial remodeling under this condition is associated with hypertrophy of cardiomyocytes in animals of both groups, which combinated with atrophy and necrosis of cells in adult rats as well as with disorganization of the stromal component, which manifested by the varying degrees of accumulation of neutral glycosaminoglycans and acid mucopolysaccharides.

The aim - to find out the peculiarities of the structural changes of the cardiomyocytes and extracellular myocardial matrix in animals of pubertal and mature age under the experimental hypercholesterolemia. 
Огляди літератури, оригінальні дослідження, погляд на проблему, випадок з практики, короткі повідомлення

Material and Methods. The studies were conducted on 24 white male rats of pubertal and mature age. Hypercholesterolemia was modeled for 30 days by feeding cholesterol with sunflower oil under suppression of thyroid function with Mercazolilum. Histological sections were stained with hematoxylin and eosin, picrofuxin by van Gizon, iron hematoxylin by Heidenhain, alcyan blue by Steadman, a portion of the histological slices were subjected to PAS reaction.

Results. Increasing of total cholesterol in blood of animals of both age groups was accompanied with morphological changes in the myocardium. Histochemical examination confirms significant manifestations of disorganization of the stromal component of the myocardium under conditions of experimental hypercholesterolemia such as accumulation of neutral glycosaminoglycans and acid mucopolysaccharides. More pronounced manifestations of the myocardial interstitium disorganization were observed in animals of mature age group. Changes of the contractile apparatus of the myocardium were manifested by hypertrophy of cardiomyocytes in animals of both age groups, atrophic and necrotic changes of cardiomyocytes were revealed in mature rats at the same time.

Conclusions. Cardiomyocytes remodeling process in pubertal rats under the experimental hypercholesterolemia has an adaptive direction and is manifested by their hypertrophy, and in adult rats it has alterative character as a manifestation of compensatory processes loss. The interstitial and perivascular edema were main changes of extracellular matrix of myocardium in young animals, and diffuse and perivascular sclerosis was dominated in adult rats.

KEY WORDS: myocardium; hypercholesterolemia; experiment; morphology. 